Research, part of a Special Feature on Twenty Years of Community Forestry in Cameroon: Opportunities and Challenges for Sustainable Development

\title{
Prioritizing enablers for effective community forestry in Cameroon
}

\author{
Lalisa A. Duguma ${ }^{1}$, Peter A. Minang ${ }^{1}$, Divine Foundjem-Tita ${ }^{2}$, Parmutia Makui ${ }^{1}$ and Serge Mandiefe Piabuo ${ }^{2}$
}

\begin{abstract}
Cameroon, in its Forestry, Wildlife and Fisheries Law 94/01 of 1994, supported local communities to engage in managing forests and benefit from them economically and environmentally. Three main objectives underlie this law: (1) enabling local communities to have access rights to forests in their surroundings, (2) Improving rural livelihoods, and (3) promoting sustainable forest management. Despite a gradual increase in the number of community forests, their effectiveness in delivering on the above objectives has been low. Our aim is to examine the typologies of the enabling factors (enablers) that could improve the performance of community forests in achieving the objectives underlying their creation. Content analysis was applied to 41 documents focusing on community forest issues in Cameroon. Benefit generation, partnership, monitoring, and policy support were the most frequently mentioned enablers with $47 \%$ of the total frequency of enablers assessed. The second enablers set, with close to $33 \%$ of the total frequency, are technical support, governance, financial support, practices choices, and institutions. We found a strong degree of association between the enablers in general. Ownership, performance, and partnership dominate this with positive association with 12,11 , and 10 other enablers, respectively. These results point to two policy and technical implications in the area of community forestry in Cameroon. First, the emergence of key sets of enablers and clusters of associations can help identify and emphasize critical leveraging points for improving effectiveness and efficiency. Second, it points to the need for holistic or integrated approaches in addressing enablers to improve community forests' performance. Further research might be needed in identifying and prioritizing corresponding policy instruments required for intervention.
\end{abstract}

Key Words: Cameroon; community forest; effectiveness; enablers

\section{INTRODUCTION}

Devolution of rights and power to manage forests has gained attention worldwide as a means of enhancing living standards for the 1.08 billion people that directly depend on forests for their livelihoods (World Bank 2004). Cameroon was one of the early countries in the Congo Basin and in Africa to embark on a forest management reform process as part of the Tropical Forest Action Plan in the late 1980s (Ekoko 2000). This led to extensive forestry reforms including a new forestry law introducing community forestry in the mid 1990s. Cameroon's Forestry, Wildlife and Fisheries Regulation Law 94/01 of 1994 (Republic of Cameroon 1994) created a great opportunity for local communities to have the right to manage and benefit from forest resources located in their surroundings. This provision in law allows communities to have access to the forests with the requirement that they obtain a legal status and sign an agreement with the government in which they commit to a set of conditions that do not affect the state of the forest while creating livelihood benefits for local people (Vabi et al. 2000). At the time, this was considered a potential game changer on how to engage local communities by giving them some degree of authority and control over forest resources located in their area, which would benefit themselves while properly managing the forests. There was great enthusiasm about this kind of forest management scheme because there were concerns that excluding local communities threatened the resources throughout Africa and in many developing nations. It was widely perceived that this model represented progressive thinking on efforts to reduce the extent of deforestation (Movuh 2012).

Community forests (CFs) are managed by communities after signing a management agreement with the government for a maximum of 5000 ha forest in nonpermanent forest estate zones (NPFE) for a period of up to 25 years, renewable. The NPFEs are open to logging and most probably have been logged in the past. Timber logging, agriculture, and income generation activities from nontimber forest products (NTFP) and ecotourism are among the common activities allowed in the CFs. Two decades after the 1994 Forestry and Wildlife Law, Cameroon registered a high number of CFs, especially in the forested parts of the country. As at 2015, CFs covered about 1.05 million ha of NPFE with a total number of $415 \mathrm{CFs}$, out of which 274 had the final management agreement and 141 were yet to finalize the provisional management agreement. Some of the CFs began operation as early as 1998/1999. When implementation began, many questions arose regarding procedures for formulating agreements with the government, e.g., how CFs should be institutionalized and governed; appropriate legal frameworks and mechanisms; how to manage the costs of institutionalizing the $\mathrm{CFs}$; and how to evaluate the effectiveness of the CF scheme. The issuance of the Manual of Procedures for the Attribution and Norms for the Management of Community Forests (Ministry of Forestry and Wildlife 2008), a document outlining the establishment and implementation procedures for community forests in Cameroon, has clarified many issues and questions behind the technical implementation of the CFs. Despite being very useful, it was argued that the manual of procedures came late, i.e., a decade after implementation began.

Undoubtedly, the community forestry scheme has succeeded in granting local communities rights to manage forests in their area. Other than that, there is no clear evidence of CF-impact on the livelihoods of the communities. Numerous researchers highlighted that in its current framing, livelihood benefits from CFs remain minimal (Oyono et al. 2004, 2012). But why did CFs, initially intended to reduce poverty for the CF members, fail to do so? Was there an overexpectation about what they could deliver? Is it a problem of mismanagement? Or is it because there are insufficient enabling conditions for it to be effective? Such 
questions attracted numerous scientific inquiries that tried to understand why the CFs could not deliver on the intended objectives and to assess which factors (enablers) should be in place for the CF schemes to be effective. Most of these studies were very localized and a synthesis of the national-level assessment that could perhaps inform policy interventions was not done.

Our aim is to identify and characterize enablers or attributes that experts and practitioners emphasized as they relate to the effectiveness of community forestry in Cameroon. Enablers are factors that influence the performance of CFs. Identifying such factors is crucial to finding leveraging points to enhance CFs' impact on forest management and poverty reduction. Such analysis helps practitioners and policy makers engaged in CFmanagement schemes to devise strategies to support communities that are managing the forests willingly.

\section{Framing the attributes of the effectiveness of community forests (CF)}

The 1994 law specified three main objectives for the creation of CFs: (1) to enable local communities have access rights to the forests in their surrounding area; (2) to reduce rural poverty for the communities managing the forests by creating income and employment opportunities; and (3) to reduce deforestation and forest degradation by increasing the participation of local communities in their management. Effectiveness therefore is about achieving these three objectives. At least two of the three objectives could be seen as competing. For instance, any access to the forest for income and employment generation could increase the likelihood of illegal activities such as slash and burn agriculture and illegal logging. Minang et al. (2007) reported an increase in the rate of deforestation and illegal timber logging in the Bimbia Bonadikombo $\mathrm{CF}$ even after the $\mathrm{CF}$ became operational. This is largely because people became aware of opportunities for exploiting the resources beyond what is legally permitted. In general, the effectiveness discourse is a very delicate balance to achieve considering the objectives set for $\mathrm{CF}$ management. The complexity of defining the boundaries for effectiveness or success in the context of CFs has also been highlighted by Pagdee et al. (2006).

To understand the enablers, two main outcomes were defined: (1) improvement in forest management, i.e., improvement in forest conditions or reduction in forest losses, e.g., due to illegal logging, and (2) poverty reduction or improved economic benefits both directly (as an individual or a community) and indirectly (mostly as a community). Direct benefit in this case refers to the dividends that reach the community. This can be from timber sale, earnings from nontimber forest products sold, ecotourism activities, employment in the CF activities, and that of logging companies, etc. The indirect benefit includes rewards and some financial and material incentives from research and educational institutions and nongovernmental organizations visiting the $\mathrm{CF}$. The indirect benefit may also include returns from the operations of community projects made within the CF. For instance, if a clinic is built from an income generated through the CF operations, it is an indirect benefit to individual members.

Reports on effectiveness of the CF scheme varied widely and there were numerous recommendations to increase/enhance the effectiveness of the scheme in delivering on the outcomes described. These recommendations are what we termed enablers of effectiveness.

\section{APPROACH}

Framing the conceptual basis for the analysis

Different authors, based on experiences from different countries, came up with a list of factors that influence the success of CFs. Among the prominent studies are: (1) Baynes et al. (2015), which assessed the success factors for community forestry in Mexico, Nepal, and the Philippines; and (2) Pagdee et al. (2006) who looked at a wide range of factors derived from 31 peer-reviewed articles globally. Several other studies also looked at specific factors influencing the success of CFs though in practice the success of a CF depends on a variety of factors that often influence one another positively or negatively. Based on the above papers and expert knowledge, we created a list of keywords that were searched for through all of the publications reviewed. Figure 1 presents a synthesis of the various enablers and the actors responsible for each. We focus on the enablers irrespective of which actor is responsible for it.

\section{METHODS}

\section{The review process: screening the publications}

We chose Scopus (https://www.elsevier.com/solutions/scopus) as the primary data source. It is the largest global database of published documents. All peer-reviewed documents were collected from Scopus using Boolean search combinations of "community forest*" "factor*," and "Cameroon." Some documents were not listed in Scopus but we knew of their existence and thus added them from Google Scholar ${ }^{\mathrm{TM}}$ to the list of documents analyzed. The search for relevant documents was limited to the two databases as per the recommendations of Yang and Meho (2006) who argued that the combination of the two provides a relatively robust source of literature. All documents published before the year 2000 were excluded from the analysis for the sole reason that any arguments about $\mathrm{CF}$ effectiveness before 2000 were largely based on opinions because very few $\mathrm{CFs}$ commenced operation before this time. The search process yielded 41 publications that were subjected to further analysis. Only publications written in the English language were selected for this study. For all the 41 publications selected, we downloaded the Portable Document Format (PDF). Figure 2 shows the distribution of the selected manuscripts across years (see Appendix 1 for the full list of selected documents).

\section{Content analysis}

Content analysis is a research technique used to analyze text data by coding qualitative information into quantitatively analyzable data (Hsieh and Shannon 2005). There are two types: conceptual analysis and relational analysis. Conceptual analysis was applied to assess the frequency of the enablers in the selected documents. See Table 1 for the list of enablers and the contents they represented. Relational analysis was used to understand how the different contexts and concepts co-occurred in the selected documents. We used probability of co-occurrence of the selected enablers and represented that in a matrix format. This relational analysis gives an insight into which issues should be looked at together with a given enabler depending on the words that 
Fig. 1. Combinations of internal and external factors influencing community forest (CFs) performance. Note: The shaded core zone refers to the internal factors and the placement of the arrows does not have any relation with the internal factors the arrow is close to.

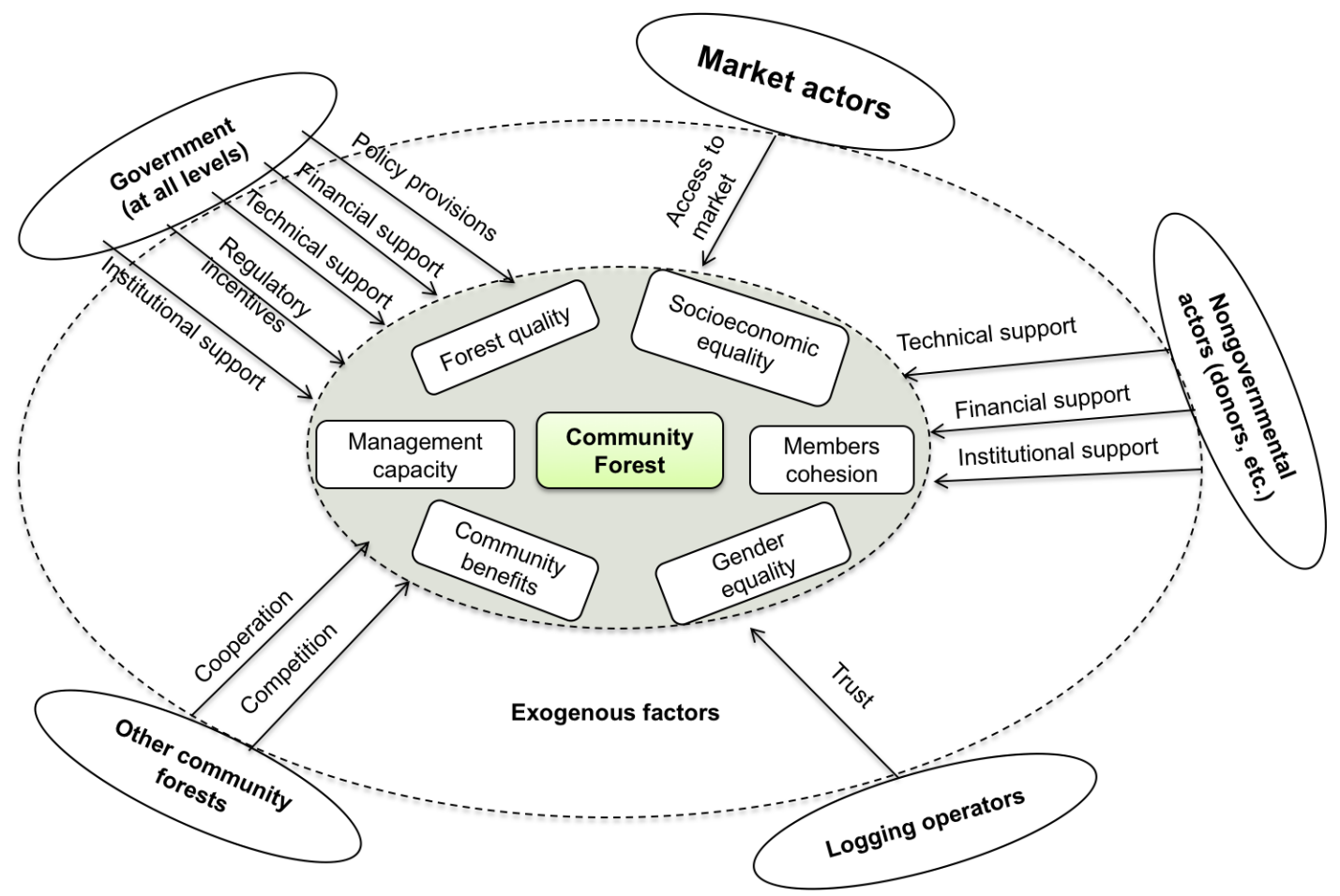

Fig. 2. Distribution of the selected publications across years.

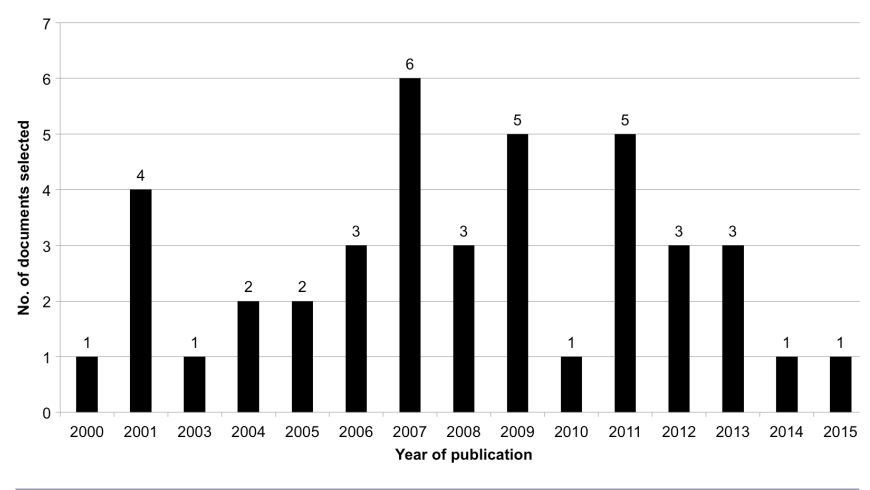

dominantly co-occur with it. The probability of co-occurrence was derived from the frequencies of the enablers in the document.

Text coding and clustering process

The enablers list was created from a list of factors that were presented in Pagdee et al. (2006) and Baynes et al. (2015) and complemented by formal and informal discussions with experts who worked with numerous CFs in Cameroon. The Pagdee et al. (2006) and Baynes et al. (2015) publications were used as the key basis for the factors/enablers identification because, unlike many publications, the two looked at a broad range of factors affecting CFs performance using case studies from the field. The context of the CFs used in the two publications is also similar to that of many developing countries' context and can be applied to Cameroon. We also held consultations with technical experts to understand how the listed factors are relevant to the Cameroon context. The technical experts represented various nongovernmental organizations working on community forests. In some cases, the discussions were done with members of the $\mathrm{CF}$ management committee.

For each enabler keyword, sets of synonyms and antonyms were specified (Table 1). This specification was based on the word frequency analysis for the 41 publications. For a word to be included either as a synonym or an antonym for an enabler, it needed to appear in any of the 41 publications considered for the analysis. To avoid erroneous exclusion of relevant words, we first developed a frequency table for all of the words in the 41 publications. In a few instances, some words were also contextually categorized under a given enabler by looking at how references were made to it in the publications. For instance, the word Baka, representing one of the indigenous pigmy communities in Cameroon, is put under "equity" because this group of people are among the marginalized groups and experience inequality. It is important to note that some enablers had more synonyms and or antonyms than others. This, however, does not affect the frequency aggregation for an enabler. If an enabler, either as is or as synonym or antonym, appears in a publication dominantly it implies that it received strong attention in that document. Hence, the number of synonyms or antonyms of a given enabler may not create a bias in the aggregation of the 
Table 1. The 20 enablers and the relevant synonyms and antonyms used.

\begin{tabular}{|c|c|}
\hline Enabler & Words of similar context either as synonym or antonym \\
\hline Benefit generation & $\begin{array}{l}\text { climate, ecology, economy, environment, nontimber forest products (NTFP), park, timber, wildlife, wood, biodiversity, } \\
\text { carbon, fish, food, greenhouse gases, habitat, harvest, livelihood, livestock, poverty, products, profit, society, species, } \\
\text { subsistence, income }\end{array}$ \\
\hline Devolve & decentralize, devolution, democracy \\
\hline Enterprise & business, export, investment, reinvest, entrepreneurship, commercial, market, employment, company, trade \\
\hline Equity & $\begin{array}{l}\text { inequality, men, women, youth, elite capture, marginalization, clan, baka, bakweri, indigenous, fairness, chief, elder, } \\
\text { tribe, Pygmy }\end{array}$ \\
\hline Financing & $\begin{array}{l}\text { financial support, financing, cost, revenue, expense, purchase, money, bank, sale, sell, fee, tax, contract, budget, funds, } \\
\text { capital, cash, price, savings, transaction, rent, input, pay }\end{array}$ \\
\hline Governance & $\begin{array}{l}\text { leadership, administration, accountability, corruption, misappropriation, preaudit, audit, election, modalities, } \\
\text { mismanagement, legitimacy, legality, enforcement, transparency, violate, representation, election, conflict, negotiation, } \\
\text { benefit sharing, empowerment }\end{array}$ \\
\hline History & precolonial, postcolonial, colonial \\
\hline Institutions & $\begin{array}{l}\text { Groupe d'Initiative Commune (GIC), Common Initiative Group (CIG), Community Forest Enterprises (CFE), } \\
\text { Community-based Forest Management (CBFM), Community-based Forest Operation (CFO), Community Forest } \\
\text { Group (CFG), committee, group, organization, village, nongovernment organization (NGO) }\end{array}$ \\
\hline Monitoring & $\begin{array}{l}\text { control, measure, demarcate, evaluation, evidence, accuracy, inventory, certification, PGIS, GIS, data, supervisory, } \\
\text { method/s, cartography, boundary, mapping, satellite, spatial, digital, compass, protect, plan, report }\end{array}$ \\
\hline Motivation & $\begin{array}{l}\text { sanctions, compensation, restriction, royalties, incentives, motivation, enthusiasm, drive, ambition, initiative, } \\
\text { determination, inspiration, incentive, stimulation }\end{array}$ \\
\hline Partnership & $\begin{array}{l}\text { relations, partnership, cooperate, collaborate, collective, communal management, membership, pluralism, participation, } \\
\text { network }\end{array}$ \\
\hline Ownership & autonomy, authority, power, tenure, concession \\
\hline Performance & outcome, output, result, benefit, impact, value, products \\
\hline Policy support & $\begin{array}{l}\text { strategy/strategies, regulation, guidelines, manual, principle, agreement, law, decree, procedure, legislation, norms, } \\
\text { resolution, protocol }\end{array}$ \\
\hline Practices & $\begin{array}{l}\text { cultivation, deforestation, degradation, restoration, rehabilitation, regeneration, logging, agriculture, reforestation, } \\
\text { plantation, program, project, initiatives }\end{array}$ \\
\hline Regulation & regulatory, regulate, rule, responsibility, respect, compliance, role \\
\hline Resource & input, infrastructure, tool, information, instrument, assistance, technology, equipment \\
\hline Right & customary, permission, access \\
\hline Sustainability & long-term, integrated, sustainable \\
\hline Technical support & training, capacity building, ability, educate, skill, learn, lesson, innovation, research \\
\hline
\end{tabular}

frequency for that particular enabler because the emphasis is on the context of that enabler rather than on the number of its synonyms or antonyms.

\section{Statistical analysis}

Contents of the PDF documents were analyzed using R software (Wickham 2009, R Core Team 2016, Feinerer and Hornik 2017, Kassambara and Mundt 2017, Wickham et al. 2017) for statistical analysis. The publications were processed by removing numbers, punctuation marks, common English words such as and, to, etc. and removing spaces. A document-term matrix was then created showing the count for each word found in the publications. From this a subset with the frequencies of the keywords of interest (enablers) was used in further analysis using descriptive statistics and correspondence analysis. Computed summaries include: total frequency of enablers from all the documents and frequency of enablers per document. A matrix showing the frequency of enablers in each of the 41 documents was used in correspondence analysis to determine the important relationships between documents and enablers in a graphical representation.

The adopted analytical approach has its own limitations. First, the use of only two databases (Scopus and Google Scholar ${ }^{\mathrm{TM}}$ ) as the sources of document selection could lead to the exclusion of important documents. Second, we based our assessment on frequencies of the enablers within the reviewed documents and the associations between the enablers. Frequency and associations alone may not always be the best representation of priority or emphasis. However, at this level of analysis it is the most feasible parameter to use because of limitations in the availability of indepth information. Third, publications produced in the French language, one of the two national languages of the country, were not considered for this analysis. Because of variations in contexts, it was difficult for the adopted analytical approach to accommodate the two languages at the same time. Despite these caveats, this study is the first to attempt to identify the enablers emphasized by practitioners with hands-on experience in community forestry in Cameroon, and we believe this synthesis captures the main priorities as reflected by the pool of experts.

A validation exercise was done with a community forest group to test whether the priority enablers identified in the literature aligns with that of the concerned communities who deal with the forest daily. In this case, Bopo CF was selected by the researchers because of its relatively better organization and extensive experience with the implementation of $\mathrm{CF}$ activities. Bopo $\mathrm{CF}$ is located in Littoral Region in Cameroon and has a total area of 3750 ha, with the majority of the land area occupied by secondary forest. The $\mathrm{CF}$, whose management agreement with the government was signed in 2007, currently has about 30 households serving as members. For this validation exercise, a 
Fig. 3. Frequency based analysis of enablers selected for the analysis. Note the different colors show the five distinct clusters based on cumulative frequency.

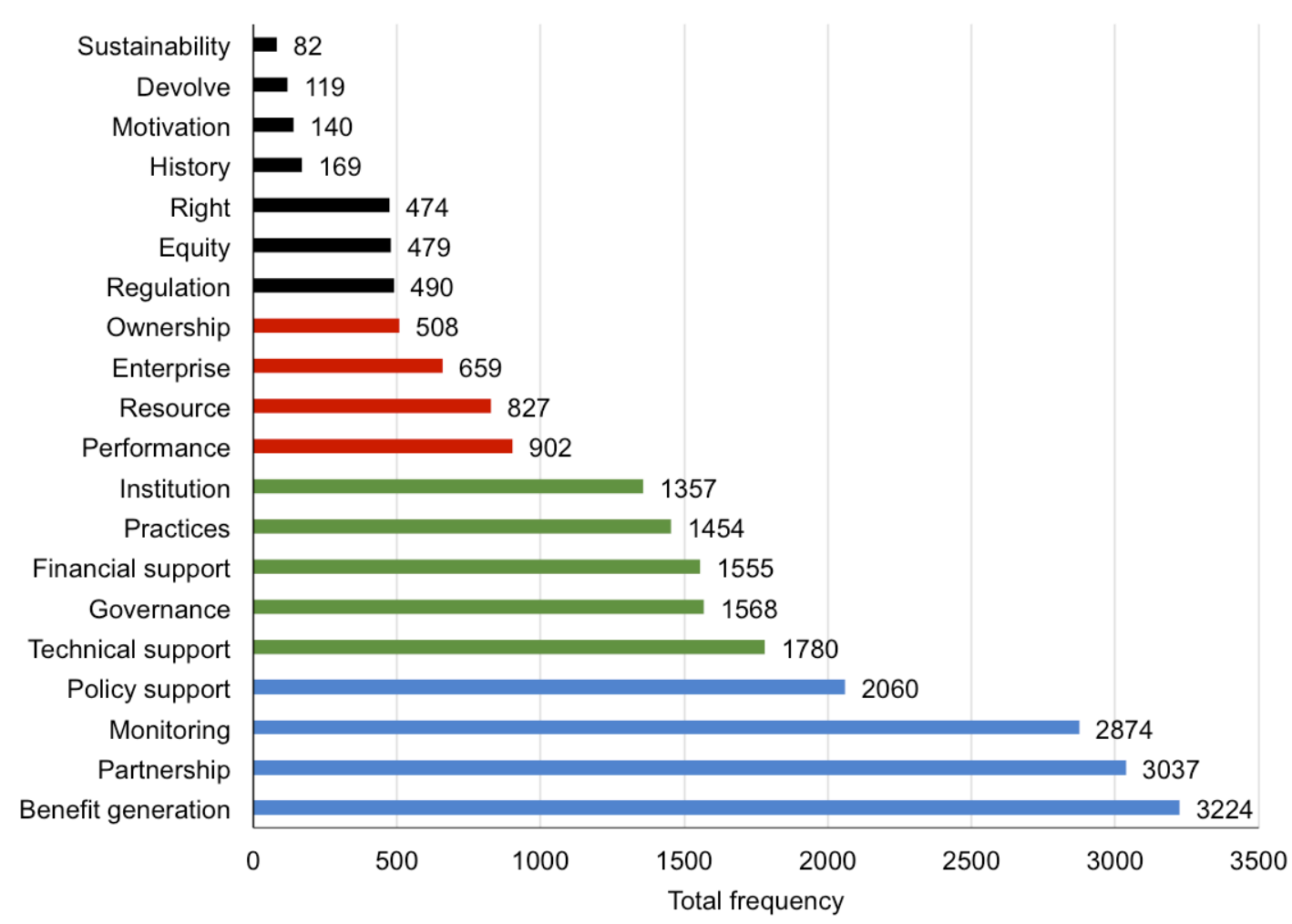

half day focus group discussion was held with 13 participants including the $\mathrm{CF}$ management committee members, the chief (local leader) of the area, the forest operations and management officer, and other households representatives in the CF. The validation activity involved listing and rating of priority factors to be emphasized to improve performance of CFs. The aim of doing so was to understand the extent of overlap between community priority factors and those found through the analysis of the literature.

\section{FINDINGS}

The level of emphasis on enablers using frequency as a measure Four distinct enabler groupings were identified (Fig. 3) depending on their cumulative frequency. The first grouping with cumulative frequency greater than 2000 comprised "benefit generation," "partnership," "monitoring of activities," and "policy support." These enablers comprised close to $47.1 \%$ of the frequency of all enablers extracted. The second most emphasized enablers grouping with frequency of 1000-2000 included: "technical support," "governance," "financial support," "practice choices" and "institutions." This grouping had a $32.5 \%$ share of the total frequency of all enablers. Together with the previous grouping, the two make up $79.3 \%$ of the total frequency of all enablers. The third grouping with a frequency of 500-1000 comprised: "performance," "resources," "enterprise" and "ownership." This third grouping made up about $12.2 \%$ of the total enablers frequency. The rest of the enablers, i.e., "regulation," "equity," "right," "history," "motivation," "devolve," and "sustainability" each had a cumulative frequency of less than 500 in all the reviewed documents. This is about an $8.2 \%$ share of the total frequency of enablers.

The validation discussion with Bopo CF showed that there is a significant overlap with the reported enablers' prioritization from the literature analysis. The following is the order of priority for the community: benefit generation, financial support, good governance, Institutional setting, technical support, practice choices, partnership, equity, monitoring of resources, and community motivation. We found an $80 \%$ overlap between the top 10 enablers listed by the Bopo community and those we found from the analysis of literature. All the priority enablers (listed above) are within the top 20 enablers identified from the literature analysis. As opposed to the findings from the literature analysis in which "policy support" ranked fourth by frequency of mention, during the validation exercise with the Bopo CF committee and members, policy-related issues were not even mentioned. They did however mention political support from national and subnational government agencies to facilitate administrative processes for the CFs.

\section{Association between the enablers}

Figure 4 shows the extent of association between the different enablers using frequency as the basis. We found that "benefit generation" had a strong association with "performance," "regulation," "financial support" and "enterprises." Our 
Fig. 4. The correlation matrix showing co-occurrences of enablers in the examined documents.

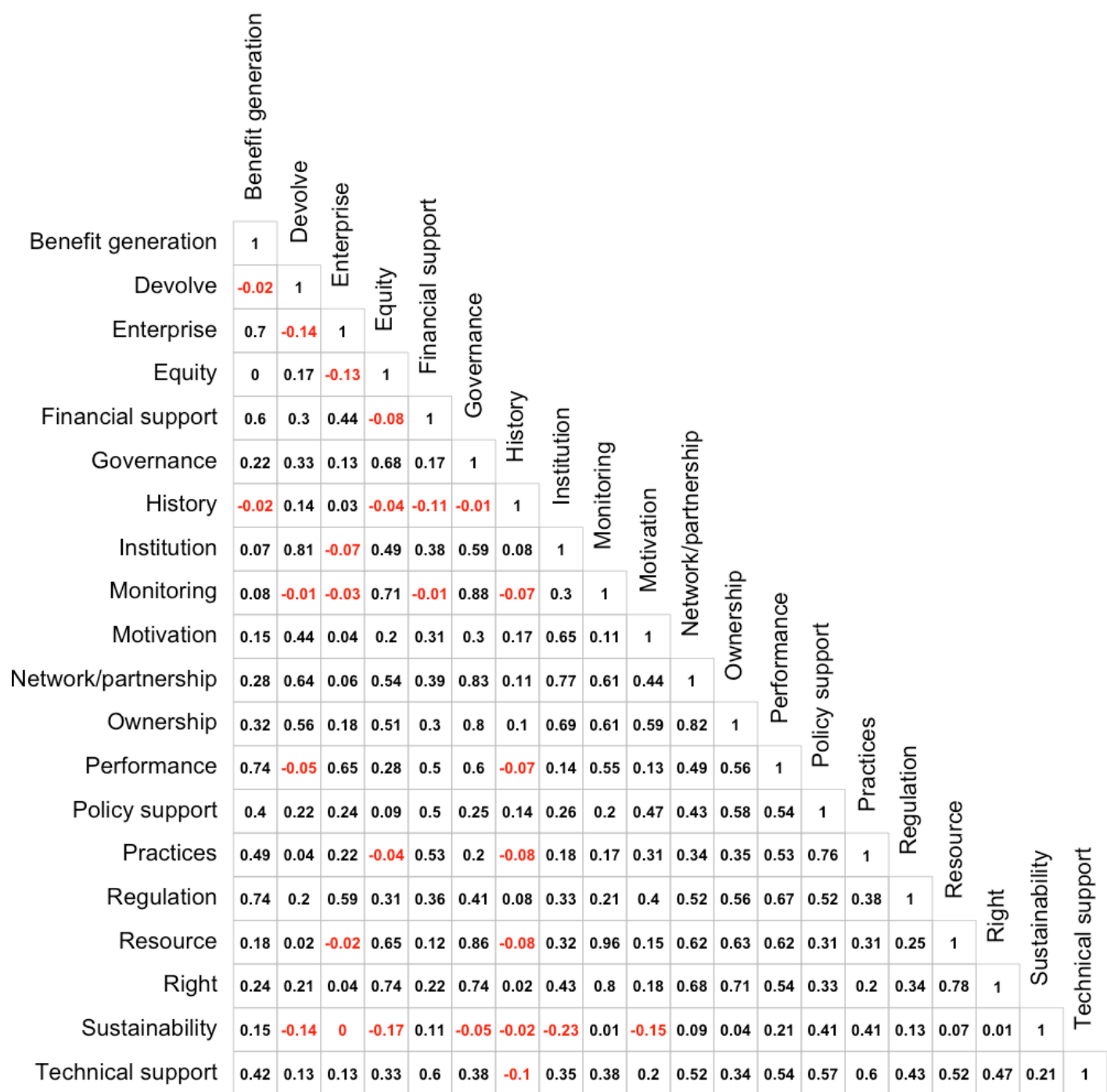

interpretation is that publications that emphasize "benefit generation" also give similar emphasis to "performance" $(0.74)$, "regulation" (0.74), "financial support" (0.60), "enterprises," $(0.70)$ and "practices" $(0.49)$. There is a clear logic in the kind of association observed. For instance, "benefit generation" potential depends on how good the CF performs and the extent of benefits (either financial or nonfinancial) depends on the types of "regulations" in place. The extent of "benefit" that can be generated also depends on the "enterprise" types comprising various "practices." "Partnership" was observed to have a very strong association with "governance" (0.83), "performance" (0.49), and "institution" (0.77). Strong "partnership" is crucial to get additional support from relevant partners. For a partnership to function well, "performance" is key and favorable "institutional" setups and appropriate "governance" mechanisms should also be in place.

The top three strong associations for the eight highly emphasized enablers were as follows:
1. Benefit generation with performance $(0.74)$, regulation (0.74), enterprises $(0.70)$

2. Partnership with governance (0.81), institution (0.77), ownership (0.82)

3. Monitoring with resources $(0.96)$, right $(0.80)$, governance (0.88), equity (0.71)

4. Policy support with practices (0.76), ownership (0.58), technical support $(0.57)$

5. Technical support with practices (0.60), financial support (0.60), policy support $(0.57)$

6. Financial support with benefit generation $(0.60)$, technical support $(0.60)$, practices $(0.53)$

7. Practices with policy support (0.76), technical support (0.60), financial support $(0.53)$

8. Institution with devolving (0.81), partnership (0.77), ownership (0.69) 
Fig. 5. Biplot of the distribution of the main enablers according to correspondence analysis; a) full data set, b) truncated to better show points other than "history."
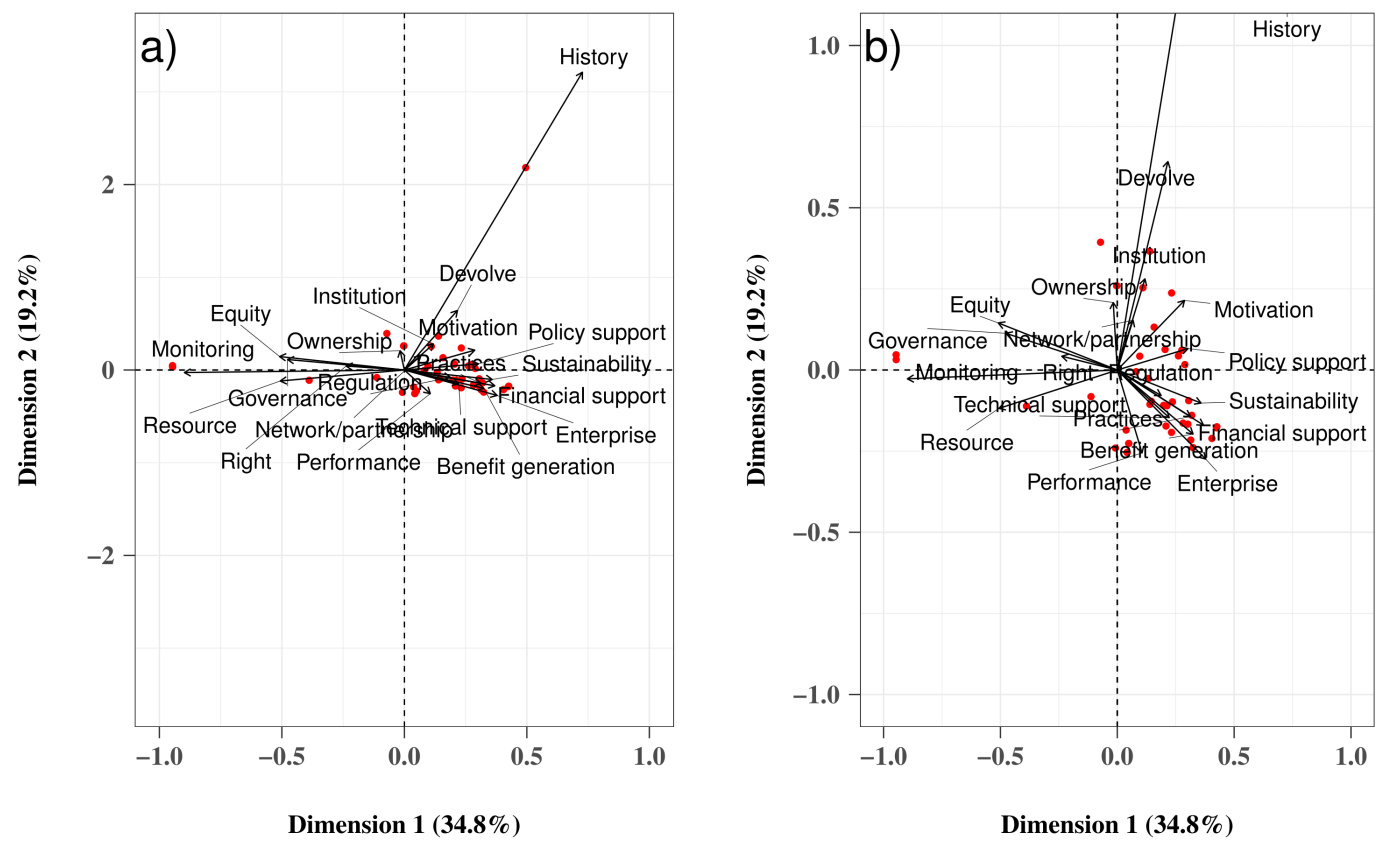

A critical look at the associations between the enablers further revealed that "ownership," "performance," and "partnership" were the most positively associated enablers with other enablers. The three enablers were positively and strongly $(r>0.5)$ associated with 12,11 , and 10 other enablers, respectively. "Governance" and "resources" had positive and strong $(r>0.5)$ associations with eight (8) enablers while "monitoring" and "right" had similar associations with seven (7) enablers. "Governance" in particular had very strong $(\mathrm{r}>0.7)$ association with "monitoring" $(0.88)$, "resources" (0.86), "partnership" (0.83), "ownership" $(0.80)$, and "rights" (0.74). This may imply that publications emphasizing "governance" also have a strong emphasis on the five enablers mentioned.

\section{Association between enablers and publications}

The results of the correspondence analysis conducted to investigate the association between enablers and publications revealed that the two main dimensions explain $54 \%$ of the total variation between publications and enablers (Fig. 5). Dimension 1 (represented along the horizontal axis) differentiates "monitoring," "equity," "governance," "resource," and "rights" from the majority of studies with "history," "financial support," and "enterprise" as strongest terms on the positive extreme. Dimension 2 is almost exclusively defined by the difference between "history" and all other terms. Enablers located close together are mostly found within the same publications, whereas publications closer together are based on similar topics. This shows that publications emphasizing "benefit generation" will most likely also emphasize "enterprises," "sustainability," "performance," and "technical support."

\section{DISCUSSION}

As described in Minang, Duguma, Bernard, et al., unpublished manuscript, CFs in Cameroon have evolved in many aspects with regard to policy over time. The government agencies responsible for the CFs have been issuing various directives, implementation plans, and other supportive strategic guidance. This policy support was largely around the establishment of the CFs and on how benefit sharing happens between the local communities, local administrations, and the ministry in charge of the CFs development. Other aspects of CFs were largely ignored and gained little attention.

The literature analysis and the validation exercise with the community confirmed the importance of attributes described in Figure 1. The literature analysis largely emphasized external factors in Figure 1 with few internal factors whereas the community consultation revealed the important significance of internal factors. For example, factors such as "ownership," "community motivation," "gender," and "youth inclusion" came out strongly at community level discussions. "Policy support," despite being one of the priorities in the literature analysis, did not come up as a key factor in the community consultation though the discussants clearly articulated the need for support from political bodies (administrations) in facilitating administrative issues affecting CFs. In both the literature and the validation exercise, factors associated with market actors and neighboring CFs (Fig. 1) did not receive strong attention. This implies CFs do not have major concerns with the enablers associated with these actors.

Two categories of priority enablers emerged: priority enablers by frequency of mention in the publications and priority enablers by degree of association between the enablers. 


\section{Priority areas of emphasis by frequency of mention in the} reviewed documents

Benefit generation, partnership, monitoring, policy support, technical support, and financial support were the top six most emphasized enablers in the documents reviewed. Due to space limitation, our discussions only focus on the first four enablers, which altogether occupied close to half the mentions of enablers in the reviewed documents.

Emphasis on the "benefit generation" aspects of CFs has dominated most of the discussion on CFs in Cameroon. Many practitioners voiced their concerns highlighting that local communities are not getting adequate benefit from activities happening in CFs (Assembe Mvondo 2006, Bigombé-Logo 2007, Oyono et al. 2012). Various factors play a role in this. The nature of institutionalization of the CFs as described in Alemagi, Minang, Duguma, et al., unpublished manuscript, has considerable influence on the extent of benefits that could be generated by CFs. Oyono (2004) also critiqued the institutional deficits that hindered CFs from progressing. Some institutional forms of CFs, such as the Common Initiative Groups (CIGs) may oblige local communities to some taxation rules that apply mostly to regular business enterprises. As described and argued by Foundjem-Tita, Duguma, Speelman, et al., unpublished manuscript, however, CFs are mainly social enterprises meant mostly for achieving development objectives of local communities that committed, through collective action, to manage forests for the good of the environment and community. When such social enterprises are subjected to regular taxation and fee rules, the benefit that goes to local communities shrinks. This may demotivate people from committing their time and energy to conserve forests. It also raises concerns about fairness because it may not be fair to impose the same taxation rules on communities that conserve forests for decades as with those actors that only appear to, at certain times, harvest timber and or other forest products.

Resource potential of CFs also influences benefit generation. Most CFs are established on secondary forest lands logged in the recent past and often do not have sufficient products to support significant benefit generation (see Cerutti and Tacconi 2006 for the case of timber). Numerous authors argued that the timber potential of many CFs in Cameroon is so low because the mature trees were already exploited in the past (Cerutti and Taconi 2006, Ezzine de Blas et al. 2009, Alemagi and Kozak 2010). Even for those with a sizeable volume of timber and other NTFPs, governance issues remained a big challenge (Piabuo et al. 2018). The most emphasized concern is the issue of elite capture, whether by urban elites or local chiefs. Elite capture occurs when some educated, urban residents from the local communities and local leaders take advantage of the lack of exposure of local communities to the outer world. It can also happen when the village leaders and local chiefs do not inform the community about the details of the revenues and other benefits generated from the community forests. Elite capture diverts the CF benefits generated from reaching the local communities (Oyono 2005, Assembe Mvondo 2006, Oyono and Efoua 2006, Nkemnyi et al. 2016). Reducing such benefits losses requires embedding the principles of good governance in the $\mathrm{CF}$ framing. For example, it is possible to urge the CF management committee to disclose financial and operational information to the concerned communities at agreed intervals.
"Partnership" plays a key role in facilitating the benefit generation process. Even though CFs are established on secondary forests, there is a potential for generating benefits if innovative interventions are adopted and the local capacity to implement such interventions are built. Such innovations could include value additions to forest products, creation of new products from NTFPs that fetch good market prices such as rattan, tooth picks, etc., and creating easy access to market by lining the community with buyers and users in high demand areas such as the urban population. The implementation of some of the innovative initiatives requires resources such as finance, equipment, skill, etc. One of the key strategies to get such resources is partnering with diverse groups of institutions that bring in different resources. For instance, research and educational institutions could provide training on forest resources management and efficient use of wood and nonwood resources in the forest. The regional forestry technicians also provide this kind of support to the CFs as mandated by the 1994 Law. Mangaoang and Cedamon (2004) emphasized that within-community research can be an effective extension tool, but continuous interactions with local communities is imperative to consolidate partnerships and share knowledge. Partnerships could also be an important avenue to get financial support for the implementation of sustainable forest management that benefit local communities. CFs could also partner directly with donors who provide grants and with banks that provide loans depending on the feasibility of the $\mathrm{CF}$ enterprises. Linking with private sector agencies and market actors creates opportunities for the CFs to have market access and better prices for their products. The emphasis on partnership by the documents reviewed is therefore justifiable even at the $\mathrm{CF}$ level.

The strong emphasis on "monitoring" of resources and activities was also justified given the growing reports of illegal activities within CFs. Reports of logging companies exploiting higher volumes of timber or areas of forest beyond what is agreed to is common (Malla et al. 2002, Brown and Lassoie 2010, Beauchamp and Ingram 2011). Besides, sometimes loggers cut trees of diverse sizes that they were not allowed to cut as specified in the agreement (Ezzine de Blas et al. 2009). Such malpractices damage the CFs potential to deliver on the primary objectives of poverty alleviation and reducing deforestation. Building the monitoring capacities of local communities is thought to be an appropriate strategy to minimize illegal exploitation and malpractices that affect the forest resource (Piabuo et al. 2018). We found little evidence suggesting that CFs master their forest. Monitoring forests using classic inventory techniques and spatial analysis procedures could be costly. Hence, some participatory approaches of resource monitoring are crucial as also argued by Minang et al (2007), e.g., by using participatory Geographical Information System (GIS) techniques and rapid participatory monitoring approaches such as participatory rural appraisal and transect walks. This kind of monitoring reveals what kinds of activities are taking place in the forest and whether the activities are legal or illegal. The participatory GIS monitoring is showing good promise in forest monitoring elsewhere. For example, Mukama et al. (2012) in Tanzania reported significant improvement in monitoring capacities of local communities after engaging in participatory forest monitoring. 
"Policy support" was among the strongly emphasized enablers in the reviewed documents. One of the major problems CFs face is the costs associated with getting the institutional recognition (Ezzine de Blas et al. 2009), the lengthy process of attaining such recognition (Movuh 2012), and the lack of clear guidance on governance structure that safeguards the benefits of local communities to the resources, e.g., by reducing the level of involvement of urban and local elites (Nkemnyi et al. 2016). Delays in the issuance of annual exploitation permits (permits without which legal exploitation activities cannot take place in $\mathrm{CFs}$ ) were quite frequent ( $\mathrm{CF}$ management committee and members, personal communication) and in other instances the permit comes late in the season when access to the forest is challenging because of poor road conditions in rainy seasons. Such delays sometimes cause CFs to skip exploitation for the year, which then can have a significant impact on the benefits generated particularly income and employment for local communities. Appropriate legislative instruments and efficiency in service delivery could reduce the pressure such impacts have on the CFs' effectiveness.

\section{Priority areas of action by degree of association between the enablers}

Considerable degrees of association were observed between the enablers assessed. Some enablers (e.g., ownership, performance, and partnership) had a positive and strong association with more than half of the enablers assessed. Such associations imply that improving CFs performance requires an integrated approach to addressing the various enablers. For instance, only providing financial support may not always be effective enough if there is limited capacity to use the availed resources, and if there is no proper governance. The current support mechanisms for CFs largely focus on one or two enablers without taking into account the ranges of associated enablers affecting the CFs effectiveness. The findings from the current analysis imply that targeting enablers separately may not be effective to achieve the major objectives underlying the creation of the community forestry scheme. Such segregated approaches to enablers may not also be efficient because the segregated targeting of enablers does not induce transformative change that leads to satisfactory delivery of benefits in a short time. It rather leads to resource wastage while inducing insignificant changes on the performances of CFs.

This study also revealed that most enablers co-occur and most of the documents assessed emphasized more than one enabler as a key area of emphasis to improve the effectiveness of CFs. This particularly calls for a system's approach to enablers such that when one of the key enablers is addressed there is a knock-on effect on the enabler/s that do have strong co-occurrence with it. Using such a system approach also simplifies targeting of the leveraging areas (interventions areas) for a higher impact in achieving effectiveness at CF level. Such targeting can also help to identify which actor/s should bring what kind of support or input to enhance effective management of $\mathrm{CFs}$, hence facilitating the processes of defining roles and responsibilities for the different actors engaged in improving CF management. Overall, the results of the current analysis could help to revisit national level priority measures to improve effectiveness of the community forestry scheme in delivering on the objectives defined at its conception. It should be noted that the current analysis was done at national level and the findings may need some contextualization if they are to be applied at a specific CF level.

\section{CONCLUDING REMARKS}

This study aimed to prioritize enablers that could enhance $\mathrm{CF}$ effectiveness to deliver on the primary objectives specified in the 1994 Forestry and Wildlife Law. We applied content analysis on 41 publications that focused specifically on CFs in Cameroon. We validated the results with a community forest group to check the level of overlap between what the literature emphasizes and what the community prioritizes. Two levels of priority enablers emerged, by frequency of emphasis and by degree of association between the enablers. We found that benefit generation, partnership, monitoring, policy support, technical support, governance, and financial support were the top seven emphasized enablers by frequency of mention in the documents reviewed. These enablers covered almost two-thirds of the enablers most frequently mentioned. The validation exercise with the Bopo CF in Littoral Region showed that there is an $80 \%$ overlap between what is identified as priority areas of emphasis within the literature and what the community cited as top 10 key issues for improving performance of CFs. In relation to the priority enablers by strong associations, ownership, performance, and partnership were the most positively associated enablers with other enablers having positive and strong associations with 12, 11, and 10 other enablers, respectively. Such associations imply the necessity to address strongly associated enablers in an integrated approach rather than focusing only on one enabler. Addressing the associated enablers from such a composite perspective could create an effective and efficient leveraging strategy to achieve improved CF performance.

The findings from this study could potentially guide policymakers and practitioners on core areas of emphasis to improve the performance of CFs and in delivering the objectives set out in the 1994 forestry law. The results give reliable guidance on where any entity trying to improve the performances of CFs against the 1994 law could invest in. They also make targeting of leveraging areas easier for actors in CF management. This has been a major knowledge gap to-date. To further ascertain the degree of impacts of the composite approach of addressing associated enablers, it is vital to conduct further empirical assessments using different combinations of enablers and to examine the changes in performances of CFs. There is a strong need to clarify who should do what and at what cost the effectiveness and efficiency of the CFs could be achieved.

Responses to this article can be read online at: http://www.ecologyandsociety.org/issues/responses. php/10242

\section{Acknowledgments:}

This paper is produced as part of the outputs for the project Financing Sustainable Community Forest Enterprises in Cameroon. The project is financially supported by UK Aid Department for International Development. We are also grateful 
for the support of the local NGOs who are supporting the implementation of this project. We are very grateful to Judith Nzyoka for the support in the publications compilation in the databases. Our special thanks to Elizabeth Kahurani-Kimani for the extensive language editing.

\section{LITERATURE CITED}

Alemagi, D., and R. A. Kozak. 2010. Illegal logging in Cameroon: causes and the path forward. Forest Policy Economics 12 (8):554-561. http://dx.doi.org/10.1016/j.forpol.2010.07.008

Assembe Mvondo, S. 2006. Forestry income management and poverty reduction: empirical findings from Kongo, Cameroon. Development in Practice 61(1):67-72. https://doi.org/10.1080/09$\underline{614520500450867}$

Baynes, J., J. Herbohn, C. Smith, R. Fisher, and D. Bray. 2015. Key factors which influence the success of community forestry in developing countries. Global Environmental Change 35:226-238. http://dx.doi.org/10.1016/j.gloenvcha.2015.09.011

Beauchamp, E., and V. Ingram. 2011. Impacts of community forests on livelihoods in Cameroon: lessons from two case studies. International Forestry Review 13(4):389-403. http://dx.doi. org/10.1505/146554811798811371

Bigombé-Logo, P. 2007. Les Régimes de tenure forestière et leurs incidences sur la gestion des forêts et la lutte contre la pauvreté au Cameroun. FAO, Rome, Italy. [online] URL: http://www.fao.org/ forestry/12717-09bdf38d000abba2b9e4d9c56e946b22e.pdf

Brown, H. C. P., and J. P. Lassoie. 2010. Institutional choice and local legitimacy in community-based forest management: lessons from Cameroon. Environmental Conservation 37(03):261-269. http://dx.doi.org/10.1017/S0376892910000603

Cerutti, P. O., and L. Tacconi. 2006. Forests, illegality, and livelihoods in Cameroon. CIFOR Working Paper no. 35. CIFOR, Bogor, Indonesia. [online] URL: http://www.cifor.org/publications/ pdf_files/WPapers/WP-35.pdfhttp://www.cifor.org/publications/pdf_files/ WPapers/WP-35.pdf

Ekoko, F. 2000. Balancing politics, economics and conservation: the case of the Cameroon Forestry Law reform. Development and Change 31(1):131-154. http://dx.doi.org/10.1111/1467-7660.00149

Ezzine de Blass, D., M. R. Pérez, J. A. Sayer, G. Lescuyer, R. Nasi, and A. Karsenty. 2009. External influences on and conditions for community logging management in Cameroon. World Development 37(2):445-456. http://dx.doi.org/10.1016/j. worlddev.2008.03.011

Feinerer, I., and K. Hornik. 2017. R: text mining package. Version 0.7-1. R Foundation for Statistical Computing, Vienna, Austria. [online] URL: https://CRAN.R-project.org/package=tm

Hsieh, H.-F., and S. E. Shannon. 2005. Three approaches to qualitative content analysis. Qualitative Health Research 15 (9):1277-1288. http://dx.doi.org/10.1177/1049732305276687

Kassambara, A., and F. Mundt. 2017. R: factoextra: extract and visualize the results of multivariate data analyses. Version 1.0.4. R Foundation for Statistical Computing, Vienna, Austria. [online] URL: $\underline{\text { htps://CRAN.R-project.org/package }=\text { factoextra }}$
Malla, Y., R. Barnes, K. Paudel, A. Lawrence, H. Ojha, and K. Green. 2002. Common property forest resource management in Nepal: developing monitoring systems for use at the local level. A report prepared by IRDD, University of Reading, UK in collaboration with Forest Action, Nepal, and ECI. Oxford University, Oxford, UK.

Mangaoang, E. O., and E. D. Cedamon. 2004. Building-up partnerships for community forestry: the ACIAR smallholder forestry project experience. Small-scale Forestry 3:353-362.

Minang, P. A., M. K. McCall, and H. Th. A. Bressers. 2007. Community capacity for implementing clean development mechanism projects within community forests in Cameroon. Environmental Management 39:615-630. http://dx.doi.org/10.1007/ $\underline{\mathrm{s} 00267-005-0275-2}$

Ministry of Forestry and Wildlife. 2008. Manuel des procedures d'attribution et des normes de gestion des forets communautaires/ Manual of procedures for the attribution and norms for the management of community forests. Republic of Cameroon, Yaoundé, Cameroon. [online] URL: http://www.forest4dev.org/ images/documents pdf/Manuel-de-procdures-et-gestion-desFC Fr Cameroon 2009 V-rsise.pdf

Movuh, M. C. Y. 2012. The colonial heritage and post-colonial influence, entanglements and implications of the concept of community forestry by the example of Cameroon. Forest Policy and Economics 15:70-77. http://dx.doi.org/10.1016/j.forpol.2011.05.004

Mukama, K., I. Mustalahti, and E. Zahabu. 2012. Participatory forest carbon assessment and REDD+: learning from Tanzania. International Journal of Forestry Research 2012:126454. http://dx. doi.org/10.1155/2012/126454

Nkemnyi, M. F., T. De Herdt, G .B. Chuyong, and T. Vanwing. 2016. Reconstituting the role of indigenous structures in protected forest management in Cameroon. Forest Policy and Economics 67:45-51. http://dx.doi.org/10.1016/j.forpol.2016.03.012

Oyono, P. R. 2004. Institutional deficit, representation, and decentralized forest management in Cameroon: elements of natural resource sociology for social theory and public policy. Environmental governance in Africa: working paper no. 15 World Resources Institute and CIFOR, Washington, D.C., USA.

Oyono, P. R. 2005. Profiling local-level outcomes of environmental decentralizations: the case of Cameroon's forests in the Congo Basin. Journal of Environment and Development 14 (3):317-337. http://dx.doi.org/10.1177/1070496505276552

Oyono, P. R., M. B. Biyong, and S. K. Samba. 2012. Beyond the decade of policy and community euphoria: the state of livelihoods under new local rights to forest in rural Cameroon. Conservation and Society 10(2):173-181. http://dx.doi.org/10.4103/0972-4923.97489

Oyono, P. R., and S. Efoua. 2006. Qui représente qui? Choix organisationnels, identités sociales et formation d'une élite forestière au Cameroun. Afrique et Développement XXXI (2):147-182. [online] URL: https://www.ajol.info/index.php/ad/ article/download/135746/125245

Pagdee, A., Y.-S. Kim, and P. J. Daugherty. 2006. What makes community forest management successful: a meta-study from community forests throughout the world. Society and Natural Resources 19(1):33-52. http://dx.doi.org/10.1080/08941920500323260 
Piabuo, S. M., D. Foundjem-Tita, and P. Minang. 2018. Community forest governance in Cameroon: a review. Ecology and Society, in press.

R Core Team. 2016. R: a language and environment for statistical computing. R Foundation for Statistical Computing, Vienna, Austria. [online] URL: https://www.R-project.org/

Republic of Cameroon. 1994. Loi $N^{o}$ 94/01 du 20 janvier 1994 portant régime des forêts, de la faune et de la pêche. [In French]. Republic of Cameroon, Yaoundé, Cameroon. [online] URL: http://www.minfof.cm/legales/Loi 94 01.pdf

Vabi, M. B., C. N. Ngwasiri, P. T. Galega, and P. R. Oyono. 2000. Devolution of responsibilities linked with forest management to local communities: context and obstacles to realisation in Cameroon. WWF-CPO Publication, Yaoundé, Cameroon.

Wickham, H. 2009. ggplot2: elegant graphics for data analysis. Springer-Verlag, New York, New York, USA.

Wickham, H., R. Francois, L. Henry, and K. Müller, RStudio. 2017. R: dplyr: a grammar of data manipulation. Version 0.7.0. R Foundation for Statistical Computing, Vienna, Austria. [online] https://CRAN.R-project.org/package=dplyr

World Bank. 2004. Sustaining forests: a development strategy. World Bank. Washington, D.C., USA. [online] URL: http:// documents.worldbank.org/curated/en/424531468781760578/pdf/297040v-1. pdf http://dx.doi.org/10.1596/0-8213-5755-7

Yang, K., and L. I. Meho. 2006. Citation analysis: a comparison of Google Scholar, Scopus, and Web of Science. Proceedings of the Association for Information Science and Technology 43(1):1-15. http://dx.doi.org/10.1002/meet.14504301185 
Appendix 1. Documents used in the analysis with some descriptive aspects.

\begin{tabular}{|c|c|c|}
\hline Full citation & Scope & $\begin{array}{l}\text { Key aspects relating to } \\
\text { enablers }\end{array}$ \\
\hline $\begin{array}{l}\text { Alemagi, D., Hajjar, R., David, S., \& Kozak, } \\
\text { R. A. (2012). Benefits and barriers to } \\
\text { certification of community-based forest } \\
\text { operations in Cameroon: An exploratory } \\
\text { assessment. Small-Scale Forestry, 1-17. }\end{array}$ & National & Certification \\
\hline $\begin{array}{l}\text { Mbile, P., Ndzomo-Abanda, G., Essoumba, } \\
\text { H., \& Misouma, A. (2009). Alternate tenure } \\
\text { and enterprise models in Cameroon: } \\
\text { Community forests in the context of } \\
\text { community rights and forest } \\
\text { landscapes. Washington: World Agroforestry } \\
\text { Centre and Rights and Resources Initiative. }\end{array}$ & National & $\begin{array}{l}\text { Resource tenure; } \\
\text { Policy support; } \\
\text { Right; } \\
\text { Enterprises }\end{array}$ \\
\hline $\begin{array}{l}\text { Cuny, P., Akem Ango, A., \& Ondoa, Z. } \\
\text { (2006). An experience of local and } \\
\text { decentralised forest management in } \\
\text { Cameroon: The case of the Kongo } \\
\text { Community Forest. In International } \\
\text { conference on managing forests for poverty } \\
\text { reduction: Capturing opportunities in forest. }\end{array}$ & $\begin{array}{l}\text { Community } \\
\text { Forest }\end{array}$ & $\begin{array}{l}\text { Devolving forest } \\
\text { management }\end{array}$ \\
\hline $\begin{array}{l}\text { Gardner, A. A., DeMarco, J., \& Asanga, C. A. } \\
\text { (2001). A conservation partnership: } \\
\text { community forestry at Kilum-Ijim, } \\
\text { Cameroon. Rural Development Forestry } \\
\text { Paper, }(25 \mathrm{H}) \text {. }\end{array}$ & $\begin{array}{l}\text { Community } \\
\text { Forest }\end{array}$ & $\begin{array}{l}\text { Benefits of community } \\
\text { forestry; } \\
\text { Conservation }\end{array}$ \\
\hline $\begin{array}{l}\text { Klein, M., Salla, B., \& Kok, J. (2001). } \\
\text { Attempts to establish community forests in } \\
\text { Lomié, Cameroon. ODI, Rural Development } \\
\text { Forestry Network paper F, } 25 .\end{array}$ & $\begin{array}{l}\text { Community } \\
\text { Forest }\end{array}$ & $\begin{array}{l}\text { Processes of establishing } \\
\text { CFs; Institutions; }\end{array}$ \\
\hline $\begin{array}{l}\text { Buchenrieder, G., \& Balgah, R. A. (2013). } \\
\text { Sustaining livelihoods around community } \\
\text { forests. What is the potential contribution of } \\
\text { wildlife domestication?. The Journal of } \\
\text { Modern African Studies, 51(1), 57-84. }\end{array}$ & & $\begin{array}{l}\text { Benefit generation; } \\
\text { Livelihood; } \\
\text { Conservation }\end{array}$ \\
\hline $\begin{array}{l}\text { Beauchamp, E., \& Ingram, V. (2011). Impacts } \\
\text { of community forests on livelihoods in } \\
\text { Cameroon: Lessons from two case } \\
\text { studies. International Forestry Review, 13(4), } \\
\text { 389-403. }\end{array}$ & $\begin{array}{l}\text { Community } \\
\text { Forest }\end{array}$ & $\begin{array}{l}\text { Benefit generation: } \\
\text { livelihood }\end{array}$ \\
\hline $\begin{array}{l}\text { Brown, H. C. P., \& Lassoie, J. P. (2010). } \\
\text { Institutional choice and local legitimacy in } \\
\text { community-based forest management: lessons } \\
\text { from Cameroon. Environmental } \\
\text { Conservation, 37(3), 261-269. }\end{array}$ & National & $\begin{array}{l}\text { Institutions; } \\
\text { Governance }\end{array}$ \\
\hline $\begin{array}{l}\text { Peach Brown, H. C., \& Sonwa, D. (2015). } \\
\text { Rural local institutions and climate change } \\
\text { adaptation in forest communities in }\end{array}$ & National & $\begin{array}{l}\text { Institutions; } \\
\text { Governance; } \\
\text { Benefits }\end{array}$ \\
\hline
\end{tabular}


Cameroon. Ecology and Society, 20(2).

Brown, H. C. P., Buck, L. E., \& Lassoie, J. P. (2008). Governance and social learning in the management of non-wood forest products in community forests in Cameroon. International Journal of Agricultural Resources, Governance and Ecology, 7(3), 256-275.

Brown, H. C. P., Lassoie, J. P., \& Wolf, S. A. (2007). An analytic approach to structuring co-management of community forests in Cameroon. Progress in Development Studies, 7(2), 135-154.

Minang, P. A., McCall, M. K., \& Bressers, H. National T. A. (2007). Community capacity for implementing Clean Development Mechanism projects within community forests in Cameroon. Environmental management, 39(5), 615-630.

Eyebe, A., Endamana, D., Sayer, J., Perez, M. R., Boedhihartono, A. K., Walters, G., ... \& Ngono, L. (2011). Community forestry and the challenge of aligning with Cameroon's green economy. Nature and Fauna, 26, 49-53. Bauer, T. (2012). Community forestry in Cameroon: how it can contribute more effectively to FLEGT. Tropenbos International. Wageningen (Policy brief). Plouvier, D., \& Eba'a Atyi, R. (2000). Community forestry in Cameroon. Prospects for development with an emphasis on market potentials. Reconnaissance mission on behalf of DFID's Cameroon Forestry Programme Coordination Support Project.

de Blas, D. E., Pérez, M. R., Sayer, J. A., Lescuyer, G., Nasi, R., \& Karsenty, A. (2009). External influences on and conditions for community logging management in Cameroon. World Development, 37(2), 445-456.

Ezzine de Blas, D., Ruiz-Pérez, M., \& Vermeulen, C. (2011). Management conflicts in Cameroonian community forests. Ecology and Society, 16(1).

Etoungou, P. (2003). Decentralization viewed from inside: The implementation of community forests in East Cameroon (No. Environmental Governance in Africa Working Paper Series (WRI) no. 12, p. 28p). World Resources Institute, Washington, DC. Djeumo, A. (2001). The development of

\begin{tabular}{|c|c|}
\hline National & $\begin{array}{l}\text { Institutions; } \\
\text { Governance; } \\
\text { Benefits }\end{array}$ \\
\hline National & $\begin{array}{l}\text { Devolve; } \\
\text { Partnership }\end{array}$ \\
\hline National & $\begin{array}{l}\text { Technical support; } \\
\text { Monitoring }\end{array}$ \\
\hline National & Policy aspects \\
\hline National & $\begin{array}{l}\text { Policy issues; } \\
\text { Benefit generation }\end{array}$ \\
\hline National & Benefit generation; \\
\hline $\begin{array}{l}\text { National but } \\
\text { with examples } \\
\text { of specific } \\
\text { cases }\end{array}$ & $\begin{array}{l}\text { Benefit generation; } \\
\text { Practices }\end{array}$ \\
\hline $\begin{array}{l}\text { National but } \\
\text { with examples } \\
\text { of specific } \\
\text { cases }\end{array}$ & Governance \\
\hline $\begin{array}{l}\text { National but } \\
\text { with examples } \\
\text { of specific } \\
\text { cases }\end{array}$ & $\begin{array}{l}\text { Devolve; } \\
\text { Governance }\end{array}$ \\
\hline National but & Institution; \\
\hline
\end{tabular}




\begin{tabular}{|c|c|c|}
\hline $\begin{array}{l}\text { community forests in Cameroon: origins, } \\
\text { current situations and constraints. Rural } \\
\text { Development Forestry Network Paper 25b. }\end{array}$ & $\begin{array}{l}\text { with examples } \\
\text { of specific } \\
\text { cases }\end{array}$ & Devolve \\
\hline $\begin{array}{l}\text { Fomété, T., \& Vermaat, J. (2001). } \\
\text { Community forestry and poverty alleviation } \\
\text { in Cameroon. Rural Development Forestry } \\
\text { Network Paper 25h. }\end{array}$ & $\begin{array}{l}\text { National but } \\
\text { with examples } \\
\text { of specific } \\
\text { cases }\end{array}$ & Benefit generation; \\
\hline $\begin{array}{l}\text { Nuesiri, E. O. (2008). Forest governance } \\
\text { challenges on Mount Cameroon. Regions: } \\
\text { Laboratories for adaptation, 27. Magazine of } \\
\text { the International Human Dimensions } \\
\text { Programme on Global Environmental } \\
\text { Change. Issue 2: } 27-30\end{array}$ & $\begin{array}{l}\text { National but } \\
\text { with a specific } \\
\text { case }\end{array}$ & Governance; \\
\hline $\begin{array}{l}\text { Oyono, P. R. (2004). Institutional deficit, } \\
\text { representation, and decentralized forest } \\
\text { management in Cameroon: elements of } \\
\text { natural resource sociology for social theory } \\
\text { and public policy (No. Environmental } \\
\text { Governance in Africa. Working Papers no. } \\
15, \text { pp. viii-56p). World Resources Institute } \\
\text { and CIFOR, Washington, DC. }\end{array}$ & National & $\begin{array}{l}\text { Institution; } \\
\text { Governance; } \\
\text { Inclusivity; } \\
\text { Equity }\end{array}$ \\
\hline $\begin{array}{l}\text { Simula, M., Ghazali, B. H., Eba'a Atyi, R., \& } \\
\text { Contreras, O. P. (2009). Developments and } \\
\text { progress in timber procurement policies as } \\
\text { tools to promote sustainable management of } \\
\text { tropical forests. Final report prepared for } \\
\text { International Tropical Timber } \\
\text { Organization, 28. }\end{array}$ & National & $\begin{array}{l}\text { Benefit generation; } \\
\text { Policies }\end{array}$ \\
\hline $\begin{array}{l}\text { Cuny, P., Ango, A. A., Ondoa, Z. A., } \\
\text { Oberndorf, R., Durst, P., Mahanty, S., .. \& } \\
\text { Suzuki, R. (2007). Local and decentralized } \\
\text { forest management in Cameroon: The case of } \\
\text { the Kongo community forest. In A Cut for the } \\
\text { Poor. FAO Conference Proceedings } \\
\text { Publications. http://www. blccarchives. } \\
\text { org/2006/07/african_human_r. html\# more. }\end{array}$ & $\begin{array}{l}\text { Community } \\
\text { forest, with } \\
\text { lessons for } \\
\text { national level }\end{array}$ & $\begin{array}{l}\text { Governance; } \\
\text { Devolve }\end{array}$ \\
\hline $\begin{array}{l}\text { Movuh, M. C. Y. (2012). Analyzing the } \\
\text { establishment of community forestry (CF) } \\
\text { and its processes examples from the South } \\
\text { West Region of Cameroon. Journal of } \\
\text { Sustainable Development, } 6(1), 76 \text {. }\end{array}$ & $\begin{array}{l}\text { National with a } \\
\text { specific focus } \\
\text { on a region }\end{array}$ & $\begin{array}{l}\text { Institutions; } \\
\text { Devolve }\end{array}$ \\
\hline $\begin{array}{l}\text { McCall, M. K., \& Minang, P. A. (2005). } \\
\text { Assessing participatory GIS for } \\
\text { community-based natural resource } \\
\text { management: claiming community forests in } \\
\text { Cameroon. The Geographical Journal, 171(4), } \\
\text { 340-356. }\end{array}$ & National & Monitoring; \\
\hline $\begin{array}{l}\text { Minang, P. A., McCall, M. K., \& Bressers, H. } \\
\text { T. A. (2007). Community capacity for } \\
\text { implementing Clean Development }\end{array}$ & National & $\begin{array}{l}\text { Monitoring; } \\
\text { Institution }\end{array}$ \\
\hline
\end{tabular}




\begin{tabular}{|c|c|c|}
\hline $\begin{array}{l}\text { Mechanism projects within community } \\
\text { forests in Cameroon. Environmental } \\
\text { management, 39(5), 615-630. }\end{array}$ & & \\
\hline $\begin{array}{l}\text { Minang, P. A., Bressers, H. T. A., Skutsch, } \\
\text { M. M., \& McCall, M. K. (2007). National } \\
\text { forest policy as a platform for biosphere } \\
\text { carbon management: the case of community } \\
\text { forestry in Cameroon. environmental science } \\
\& \text { policy, 10(3), 204-218. }\end{array}$ & National & $\begin{array}{l}\text { Policy; } \\
\text { Benefit generation }\end{array}$ \\
\hline $\begin{array}{l}\text { Movuh, M. C. Y (2012). The colonial } \\
\text { heritage and post-colonial influence, } \\
\text { entanglements and implications of the } \\
\text { concept of community forestry by the } \\
\text { example of Cameroon. Forest policy and } \\
\text { economics, 15, 70-77. }\end{array}$ & National & $\begin{array}{l}\text { History; } \\
\text { Governance }\end{array}$ \\
\hline $\begin{array}{l}\text { Njoh, A. J. (2007). Politico-economic } \\
\text { determinants of forestry policy in } \\
\text { Cameroon. GeoJournal, } 70(2), 109-120 .\end{array}$ & National & $\begin{array}{l}\text { Benefit generation; } \\
\text { Policy support }\end{array}$ \\
\hline $\begin{array}{l}\text { Nkongmeneck, B. A., Caspa, R., \& Fedoung, } \\
\text { E. F. (2013). Tropical Rainforests of Africa: } \\
\text { Can conservation projects reconcile forest } \\
\text { conservation and development of } \\
\text { forest-dependent communities?. In Treetops } \\
\text { at Risk (pp. 401-404). Springer New York. }\end{array}$ & National & Benefit generation; \\
\hline $\begin{array}{l}\text { Ofoulhast-Othamot, G. (2014). } \\
\text { Decentralization of natural resources } \\
\text { management and improvement of rural } \\
\text { livelihoods: empirical evidence from the } \\
\text { Dimako Council Forest experiment in eastern } \\
\text { Cameroon. Forests, Trees and } \\
\text { Livelihoods, 23(3), 175-187. }\end{array}$ & $\begin{array}{l}\text { National with } \\
\text { specific case }\end{array}$ & $\begin{array}{l}\text { Devolve; } \\
\text { Governance; } \\
\text { Benefit generation }\end{array}$ \\
\hline $\begin{array}{l}\text { Oyono, P. R. (2004). One step forward, two } \\
\text { steps back? Paradoxes of natural resources } \\
\text { management decentralisation in } \\
\text { Cameroon. The Journal of Modern African } \\
\text { Studies, 42(1), 91-111. }\end{array}$ & National & $\begin{array}{l}\text { Governance; } \\
\text { Devolve }\end{array}$ \\
\hline $\begin{array}{l}\text { Oyono, P. R., Biyong, M. B., \& Samba, S. K. } \\
\text { (2012). Beyond the decade of policy and } \\
\text { community euphoria: The state of livelihoods } \\
\text { under new local rights to forest in rural } \\
\text { Cameroon. Conservation and Society, 10(2), } \\
173 \text {. }\end{array}$ & National & $\begin{array}{l}\text { Policy; } \\
\text { Benefit generation; } \\
\text { Rights }\end{array}$ \\
\hline $\begin{array}{l}\text { Oyono, R. P. (2005). Profiling local-level } \\
\text { outcomes of environmental decentralizations: } \\
\text { the case of Cameroon's forests in the Congo } \\
\text { Basin. The Journal of Environment \& } \\
\text { Development, 14(3), 317-337. }\end{array}$ & National & $\begin{array}{l}\text { Benefit generation; } \\
\text { Devolve }\end{array}$ \\
\hline $\begin{array}{l}\text { de Blas, D. E., Pérez, M. R., Sayer, J. A., } \\
\text { Lescuyer, G., Nasi, R., \& Karsenty, A. } \\
\text { (2009). External influences on and conditions }\end{array}$ & National & $\begin{array}{l}\text { Benefit generation; } \\
\text { Regulations; } \\
\text { Partnership }\end{array}$ \\
\hline
\end{tabular}


for community logging management in Cameroon. World development, 37(2), 445-456.

Sonwa, D., Weise, S. F., Tchatat, M., National with a Practices choices; Nkongmeneck, B., Adesina, A. A., Ndoye, O., ... \& Malleson, R. (2001). The role of cocoa agroforests in community and farm forestry in southern Cameroon. Network Paper, 25.

Thies, W., Von Pfeil, E., Reiche, M., \& Dräger, D. (2006). Forest strategy of German Development Cooperation with Africa. International Forestry Review, 8(1), 168-177.

Mbile P, and Misouma A. (2008). Towards Alternative Tenure and Forest Enterprise Models contexts: An Overview of the History and Evolution of Forest Policy, Property Rights, Industry and Trade in Cameroon. Working Paper Submitted to the Rights and Resource Initiative (RRI).

Usongo, L., \& Nkanje, B. T. (2004). Participatory approaches towards forest conservation: the case of Lobéké National Park, South East Cameroon. The International specific region Benefit generation in focus

Continental

with a particular case on Cameroon

National

National with specific case on a region
Policy;

Partnership

Enterprise;

History;

Policy

\section{Monitoring;}

Benefit generation;

Policy support

Ecology, 11(2), 119-127. 